\title{
Analysis of Thermal Bridge Impact in a Hotel Building for the Eight Brazilian Bioclimatic Zones
}

\author{
Eduardo Grala da Cunha and Beatriz Echenique Gioielli \\ DTC (Department of Construction Technology), Architecture Faculty, Federal University of Pelotas, Pelotas 96020-240, Brazil
}

\begin{abstract}
This article aims to present an analysis of the influence of thermal bridges on reinforced concrete structural systems regarding energy performance of the envelope of a commercial building located in the bioclimatic zones 1 to 8 in Brazil, using computer simulation. The method used to achieve this goal includes the following steps: (1) definition and configuration of the base case; (2) definition and configuration of the reference model; (3) optimization of energy modeling; (4) energy modeling and comparison of consumption between the base case and the reference model. Main results showed that thermal bridges in reinforced concrete interfere on the building's energy performance and that the impact is related to the WWR (window-to-wall ratio) on the building. For hotel buildings with WWR from $30 \%$ to $45 \%$, thermal bridges imply a decrease in estimated consumption, which can reach $10 \%$, depending on the bioclimatic zone. For $60 \%$ WWR, the non-consideration of thermal bridges can represent up to $5 \%$ of increase in estimated consumption, depending on the Brazilian bioclimatic zone.
\end{abstract}

Key words: Thermal bridge, thermal performance, energy efficiency.

\section{Introduction}

In Brazil, the new standards of energy performance and efficiency are recent and still do not impact Brazilian people's lives in a significant way. In some cases, we still face techniques and construction systems that are inadequate for the country's different climatic contexts and they often result in low levels of thermal comfort for the users. The greater purchasing power, together with constructive solutions that are inadequate to the bioclimatic point of view, has highly increased the buildings' energy consumption. The first standard for thermal performance and energy efficiency was published in the last few years. ABNT (Brazilian Technical Standards Association) has approved two standards: NBR (British Standard) 15.575-Housing Buildings Performance [1] and NBR 15.220-Buildings Thermal Performance [2].

The standard [1] is wide and proposes to analyze performance requirements, criteria and evaluation

\footnotetext{
Corresponding author: Eduardo Grala da Cunha, Dr., research field: energy efficiency. E-mail: eduardogralacunha@yahoo.com.br.
}

methods, from structural performance, tightness of windows, thermal, acoustic and lighting performance to the buildings' environmental adequacy, durability and maintainability. In its third part, the standard [2] defines recommendations regarding thermal comfort for single-family dwellings with a social interest, indicating guidelines for construction and the most adequate strategies for several bioclimatic zones. However, many of the requirements of these standards, especially those related to physical features of the closures (thermal transmittance, thermal delay, solar heat), have been questioned in researches.

Some authors like Matos [3] and Pereira [4] have proved, in their studies, that some of the criteria adopted by the standards are inadequate or mistaken, for the NBR 15.575 [1], which came out after NBR 15.220 [2].

It was possible to observe how important it is to have recommendations for projects that can be trusted, thanks to Venâncio's [5] research, which proved that more than $50 \%$ of the architects, consultants and researchers adopt these recommendations as the most frequent tool when making decisions. 
Several works focus on the analysis of thermal performance of envelopes, however, most of them concentrate on solar radiation with opaque and transparent closures. Carlo's [6] doctorate research became a reference when she made more than 1,000 computer simulations with the Energy Plus software. Based on her work, the equations of linear regression found on the Brazilian Technical Regulation for Energy Efficiency in Commercial, Services and Public Buildings-RTQ-C [7] were formulated, in order to evaluate the envelopes' energy efficiency levels in commercial, services and public buildings, through a prescriptive method. Not many academic works in Brazil focus on analyzing the impact of thermal bridges regarding thermal performance, neither in residential nor commercial buildings.

Internationally, negative consequences of thermal bridges have been recognized and strategies for their corrections are adopted. Thermal bridges increase the risk of superficial condensations and formation of filamentous fungi. Also, due to their nature, they serve as a path for heat transmittance, aggravating loss of heat to the outside, which can generate more energy consumption for heating. According to Evans and Schiller [8], thermal bridges favor superficial condensation and the Argentinian regulation IRAM (Argentine Institute for Standardization and Certification) [9] states that thermal bridges cause a higher heat flux, which originates superficial condensation. In this same context, Haupt [10] says that thermal bridges generate a fast decrease of surface temperatures, which can cause superficial condensation. As a direct consequence of superficial condensation, most times, filamentous fungi appear. The effects of thermal bridges are still neglected or poorly put into calculations in the studies of heat transmittance in buildings in Brazil. This mostly happens because heat transfer in buildings has been considered unidimensional. According to Haupt [10], there is a thermal bridge when the thermal flux stops being unidimensional. Valério [11] states that thermal bridge is every part of a building's envelope in which it is not possible to admit the hypothesis of a unidirectional heat flux. Thus, the calculation approach to analyzing buildings' thermal performance conventionally used is no longer valid, since it considers the uniform elements' thermal resistance for its area. Regarding phenomena of physics, in the thermal bridges zones, the lines of heat flux stop being rectilinear, which would be typical of a unidirectional process (Fig. 1) and take the directions in which the resistance to heat transfer is lower.

Thinking this way, it is possible to notice how important it is to quantify the loss or the gain of heat created by thermal bridges. They interfere with a building's thermal comfort and energy performance, as well as on its tendencies to pathologies.

In this way, the article aims to present an analysis of the influence of thermal bridges on reinforced concrete structural systems regarding energy performance of the envelope of a commercial building located in the bioclimatic zones 1 to 8 in Brazil, using computer simulation. The country is divided into eight different bioclimatic zones, which represent the Brazilian different climatic conditions. The Brazilian bioclimatic zoning is presented in Fig. 2.

\section{Method}

The research was conducted in four stages. In the first one, we defined the typology to be used, taking into consideration the use and occupation characteristics, as well as the internal load density. In this way, we chose a hotel, which combines residential occupancy with the internal load density of commercial buildings.

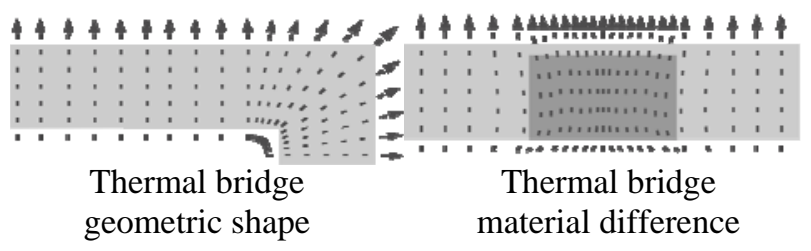

(a)

(b)

Fig. 1 Examples of thermal bridges in built envelope [11]: (a) geometric shape; (b) material difference. 


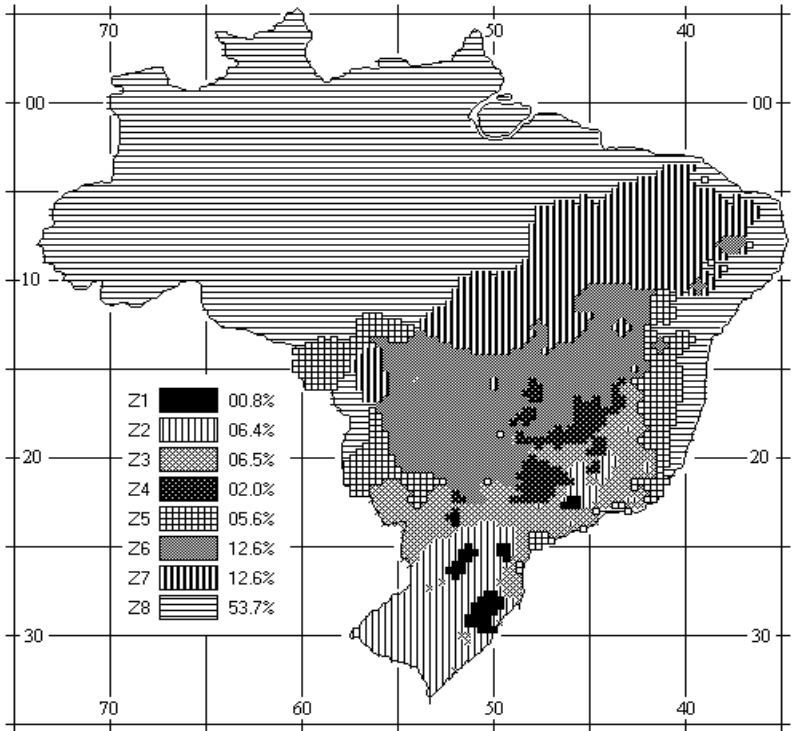

Fig. 2 Brazilian bioclimatic zoning [2].

After defining typology, the research continued to its second stage: the building's modelling and configuration. The software used for this was DesignBuilder, version 3.0.0.15, considering presence and absence of thermal bridges regarding the concrete structure for modelling. Due to the software's limitations for modelling thermal bridges, an adaptation of the model was needed, so that it could interpret thermal bridges. For this, equivalent walls were calculated. In order to improve the time needed for making simulations, the simulations themselves were optimized. This was the third stage of the research, described hereafter.

Having the models with and without thermal bridges ready and configured on DesignBuilder, energy modeling started - the fourth stage of the research.

The hotel model was simulated with different configurations: with WWR (window-to-wall ratio) alterations (30\%, 45\% and 60\%), lighting density and equipment load density, based on the NBR 16401 [12] and the RTQ-C [7] standards. These parameters resulted into 36 simulated configurations for each of the eight Brazilian bioclimatic zones.

\subsection{Definition and Configuration of Base Case}

The base case was defined as hotel for presenting the residential and commercial characteristics already mentioned, occupied during the entire day. Based on the typology analysis of Carlo [6] (Table 1), volume and percentage of window area on the facade were defined. Carlo [6] searched commercial typologies in five Brazilian capitals, to define base cases to be energy modeled in order to define the parameters to develop the Brazilian Energy Efficiency Regulation. From these data, we created an architecture project which was later on modeled with DesignBuilder, version 3.0.0.15. The model was configured according to the parameters of hotel typology used on the reference presented in Table 1.

\subsection{Definition of Equivalent Wall}

To make it possible to configure the external walls on DesignBuilder, considering that masonry presents a heterogeneous composition, it was necessary to build an equivalent wall, composed by plaster, ceramic, air gap, ceramic and plaster with the same transmittance and thermal capacity of the original wall. This equivalent wall is presented in Fig. 3.

Table 1 Parameters and variables of the base model.

\begin{tabular}{lll}
\hline Parameters & Variables & \\
\hline Dimension & $52 \mathrm{~m} \times 17 \mathrm{~m}$ & \\
Number of floors & 5 & \\
WWR & $30 \%$ & \\
\hline \multirow{3}{*}{ Glazing type } & Color & Colorless \\
& Thickness & $4 \mathrm{~mm}$ \\
\hline Wall & Film & No \\
\hline Occupancy (density) & 0.28 people $/ \mathrm{m}^{3}$ & \\
\hline Internal gains & Lighting & $21 \mathrm{~W} / \mathrm{m}^{2}$ \\
& Equipment & $60 \mathrm{~W} / \mathrm{m}^{2}$ \\
\hline & $0: 00-6: 00$ & $100 \%$ \\
& $7: 00-15: 00$ & $50 \%$ \\
Schedule & $16: 00-24: 00$ & $75 \%$ \\
(weekdays; holidays) & $0: 00-6: 00$ & $60 \%$ \\
& $7: 00-15: 00$ & $30 \%$ \\
& $16: 00-24: 00$ & $40 \%$ \\
\hline Air conditioning & Split & COP (performance \\
system & & coefficient) 3.21 \\
& & \\
& & heating/cooling) \\
\hline
\end{tabular}


In Table 2, thermal properties of the wall's materials are characterized. Considering the thicknesses alterations on this new equivalent wall, it was necessary to adjust the density of apparent mass of ceramics.

\subsection{Definition and Configuration of the Reference} Model

To reach transmittance parameters of $1.92 \mathrm{~W} / \mathrm{m}^{2} \mathrm{~K}$ determined on the base case and represent thermal

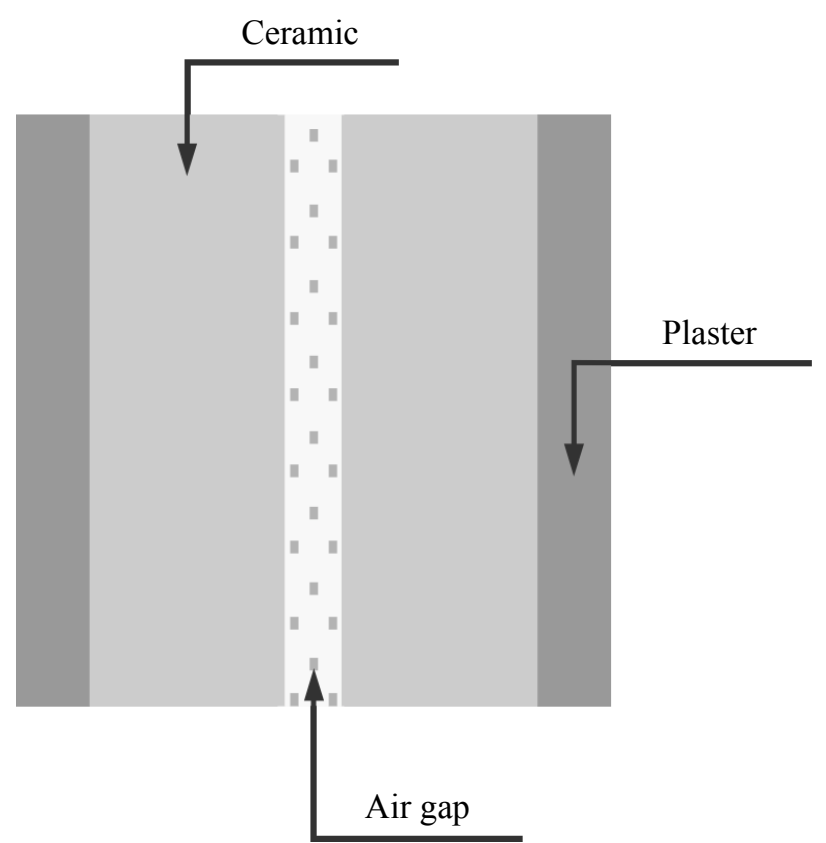

Fig. 3 Equivalent wall.

Table 2 Materials and parameters of the equivalent wall.

\begin{tabular}{lll}
\hline Materials & \multicolumn{2}{c}{ Parameters } \\
\hline System (wall) & Heat capacity & $202 \mathrm{~kJ} / \mathrm{km}^{2}$ \\
\hline \multirow{3}{*}{ Plaster } & Thickness & $0.025 \mathrm{~m}$ \\
& Density & $2,000 \mathrm{~kg} / \mathrm{m}^{3}$ \\
& Specific heat capacity & $1.00 \mathrm{~kJ} / \mathrm{km}^{2}$ \\
\hline \multirow{3}{*}{ Ceramic } & Thickness & $0.076 \mathrm{~m}$ \\
& Density & $739.13 \mathrm{~kg} / \mathrm{m}^{3}$ \\
& Specific heat capacity & $0.92 \mathrm{~kJ} / \mathrm{km}^{2}$ \\
\hline Air gap & Thickness & $0.02 \mathrm{~m}$ \\
\hline \multirow{3}{*}{ Ceramic } & Thickness & $0.076 \mathrm{~m}$ \\
& Density & $739.13 \mathrm{~kg} / \mathrm{m}^{3}$ \\
& Specific heat capacity & $0.92 \mathrm{~kJ} / \mathrm{km}^{2}$ \\
\hline \multirow{3}{*}{ Plaster } & Thickness & $0.025 \mathrm{~m}$ \\
& Density & $2000 \mathrm{~kg} / \mathrm{m}^{3}$ \\
& Specific heat capacity & $1.00 \mathrm{~kJ} / \mathrm{km}^{2}$ \\
\hline
\end{tabular}

bridges on DesignBuilder, we calculated an equivalent wall modeled with three subsurfaces (a modelling tool of this software, which allows superposition of layers): the heavyweight wall, representing concrete beams and pillars with plaster; lightweight wall, made of agglomerate and concrete and internal wall, entirely made of concrete, as shown in Fig. 4. In Table 3, materials and their parameters are detailed.

\subsection{Review and Definition of the Internal Load} Density (Equipment and Lighting)

Equipment load was defined based on Carlo [6] (60 $\mathrm{W} / \mathrm{m}^{2}$ ). In order to question this parameter, we also used the parameters of equipment load density suggested by NBR 16401 [12] for comparison. We simulated with a lighting density $\left(6 \mathrm{~W} / \mathrm{m}^{2}\right)$, medium lighting density $\left(11 \mathrm{~W} / \mathrm{m}^{2}\right)$ and high lighting density $\left(21 \mathrm{~W} / \mathrm{m}^{2}\right)$ loads.

The lighting load suggested by Carlo [6] is 21 $\mathrm{W} / \mathrm{m}^{2}$. However, standards recommended by the RTQ-C [7] for a hotel were used: $10.8 \mathrm{~W} / \mathrm{m}^{2}$ for level A; $12.4 \mathrm{~W} / \mathrm{m}^{2}$ for level $\mathrm{B} ; 14 \mathrm{~W} / \mathrm{m}^{2}$ for level $\mathrm{C} ; 15.7$ $\mathrm{W} / \mathrm{m}^{2}$ for level $\mathrm{D}$.

\subsection{Definition of Setpoints of Heating and Cooling}

In the configuration of environmental control, the heating setpoint was put at $22{ }^{\circ} \mathrm{C}$ and the heating

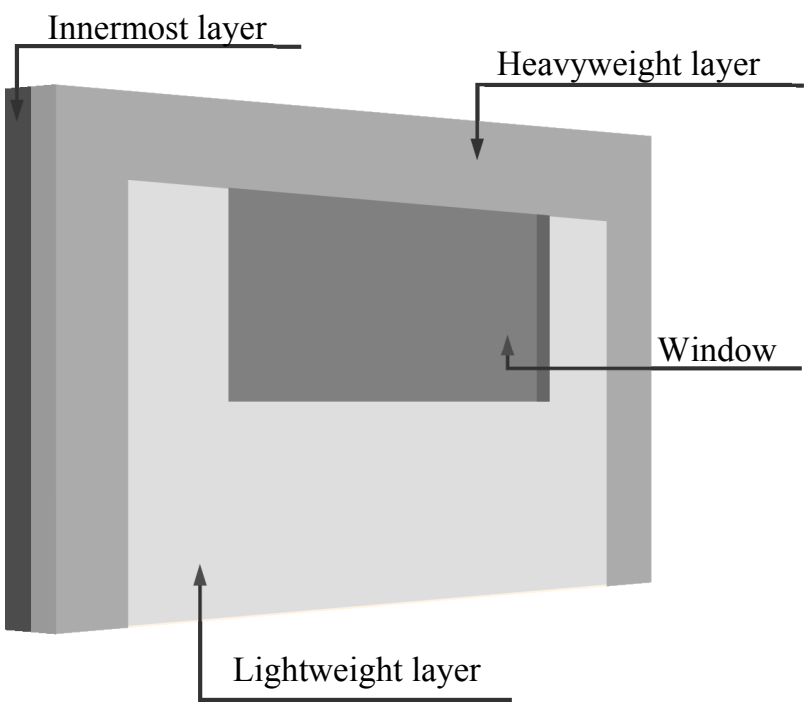

Fig. 4 Modeled equivalent wall. 
Table 3 Parameters of equivalent wall.

\begin{tabular}{|c|c|c|c|}
\hline Layers & Materials & & meters \\
\hline \multirow{3}{*}{ Innermost layer } & \multirow{3}{*}{ Concrete } & Thermal conductivity & $1.75 \mathrm{~W} / \mathrm{mK}$ \\
\hline & & Thickness & $0.08 \mathrm{~m}$ \\
\hline & & Density & $2,400 \mathrm{~kg} / \mathrm{m}^{3}$ \\
\hline \multirow{6}{*}{ Lightweight layer } & \multirow{3}{*}{ Concrete } & Thermal conductivity & $1.75 \mathrm{~W} / \mathrm{mK}$ \\
\hline & & Thickness & $0.062 \mathrm{~m}$ \\
\hline & & Density & $2,400 \mathrm{~kg} / \mathrm{m}^{3}$ \\
\hline & \multirow{3}{*}{ Agglommerate } & Thermal conductivity & $0.058 \mathrm{~W} / \mathrm{mK}$ \\
\hline & & Thickness & $0.0172 \mathrm{~m}$ \\
\hline & & Density & $338.46 \mathrm{~kg} / \mathrm{m}^{3}$ \\
\hline \multirow{6}{*}{ Heavyweight layer } & \multirow{3}{*}{ Concrete } & Thermal conductivity & $1.75 \mathrm{~W} / \mathrm{mK}$ \\
\hline & & Thickness & $0.1 \mathrm{~m}$ \\
\hline & & Density & $2,400 \mathrm{~kg} / \mathrm{m}^{3}$ \\
\hline & \multirow{3}{*}{ Plaster } & Thermal conductivity & $1.15 \mathrm{~W} / \mathrm{mK}$ \\
\hline & & Thickness & $0.02 \mathrm{~m}$ \\
\hline & & Density & $2,000 \mathrm{~kg} / \mathrm{m}^{3}$ \\
\hline
\end{tabular}

setback to $21{ }^{\circ} \mathrm{C}$. Cooling setpoint was put at $24{ }^{\circ} \mathrm{C}$ and cooling setback at $25.5^{\circ} \mathrm{C}$. Setpoints were defined based on NBR 16401 [12].

\subsection{Energy Modeling Optimization}

Optimization of simulations aimed to enhance the high number of simulations carried on. The process of creating new IDFs (input data file) happened through the development of an analyzer, which goes through the base IDFs and modifies them, so that each new one has its own lighting and equipment properties.

For modifying an IDF and generating a new one, it is necessary to know its LPD (lighting power density) and ILD (internal load density), both the original and the new ones. The following Eqs. (1) and (2) were used in this process:

$$
\begin{gathered}
\text { Design Lighting Level }=\frac{L P D(\text { original })}{I L D(\text { original })} \times L P D(\text { new }) \\
\text { Design Equipment Level }=\frac{L P D(\text { original })}{I L D(\text { original })} \times I L D(\text { new })
\end{gathered}
$$

At the end of each new IDF, for the simulator to generate results based on the amount of energy spent in lighting, equipment, heating and cooling, we insert the following output rules:

- output: meter, interior light: electricity, daily;

- output: meter, interior equipment: electricity, daily;

- output: meter, district heating: facility, daily;

- output: meter, district cooling: facility, daily.

Having all the IDFs, the next step is the simulation. In this one, we used the software BCVTB (Building Controls Virtual Test Bed), for making co-simulations from a real time message exchange with other softwares. In Fig. 5, it is possible to see the connection between EnergyPlus and MATLAB.

EnergyPlus is a software designed for simulating thermal load and energy analysis of buildings and their systems.

For the simulation to be carried on with BCVTB, firstly, we configure the bioclimatic file used and the following variables:

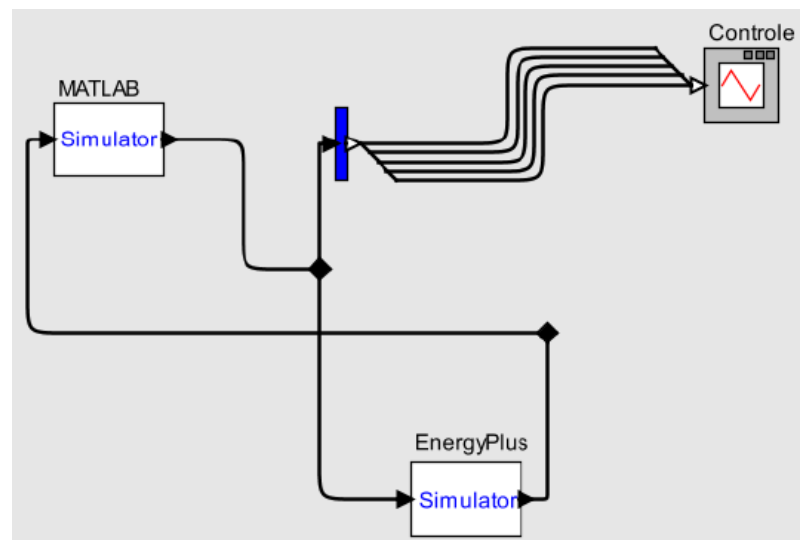

Fig. 5 Interface of BCVTB. 


$$
\begin{gathered}
\text { Start Time }=0 \mathrm{~s} \\
\text { Final Time }=12 \times 31 \times 24 \times 3,600 \mathrm{~s} \\
\text { Time Step }=3,600 \mathrm{~s}
\end{gathered}
$$

They are, respectively, start time and final time of a simulation. In this way, we have a simulation during one year, with daily results.

BCVTB can be executed through its standard interface or also through a command line, which can be explored by any programming language.

Both BCVTB and EnergyPlus work with one IDF at a time. To solve this problem, another tool was developed, to automatically execute BCVTB for each IDF and after the simulation, this tool creates tables and graphics, for a better analysis of the data obtained through simulation.

\subsection{Energy Modeling and Comparison of} Consumption between the Base Case and the Reference Model

With the case base and the reference model, with and without thermal bridges, respectively, modeled and configured on DesignBuilder, we started simulations. For the first data generated, Carlo's [6] parameters were used. After the first simulations, we confirmed that the ILD of $60 \mathrm{~W} / \mathrm{m}^{2}$ was out of the regulation parameters. Using the different parameters of load and lighting density, referred by NBR 16401 [12] and RTQ-C [7] standards, 36 configurations to be simulated, with and without thermal bridges, were generated.

\section{Results and Discussions}

Models were simulated with and without thermal bridges and varying configurations of ILD, LPD and WWR for every bioclimatic zone. The results of the energy modeling were compiled in tables. From these tables, we created graphics (Fig. 6 and Table 4), which show the bioclimatic zones in the abscissas, numbered from 1 to 8 , and the difference between annual consumption of models with and without thermal



Fig. 6 Energy modeling results for five zones-annual consumption.

Table 4 Energy modeling results for five zones-annual consumption.

\begin{tabular}{lllllll}
\hline \multirow{2}{*}{ Bioclimatic zone } & $\begin{array}{l}\text { WWR 30\% } \\
\text { min ILD/LPD }\end{array}$ & $\begin{array}{l}\text { WWR 30\% } \\
\text { max ILD/LPD }\end{array}$ & $\begin{array}{l}\text { WWR 45\% min } \\
\text { ILD/LPD }\end{array}$ & $\begin{array}{l}\text { WWR 45\% max } \\
\text { ILD/LPD }\end{array}$ & $\begin{array}{l}\text { WWR 60\% min } \\
\text { ILD/LPD }\end{array}$ & $\begin{array}{l}\text { WWR 60\% max } \\
\text { ILD/LPD }\end{array}$ \\
\hline 1 & $10.33 \%$ & $9.13 \%$ & $9.15 \%$ & $7.96 \%$ & $-2.06 \%$ & $-3.09 \%$ \\
2 & $4.23 \%$ & $4.79 \%$ & $3.98 \%$ & $4.21 \%$ & $-3.66 \%$ & $-4.40 \%$ \\
3 & $5.73 \%$ & $4.57 \%$ & $5.06 \%$ & $4.06 \%$ & $-2.86 \%$ & $-3.93 \%$ \\
4 & $4.49 \%$ & $4.49 \%$ & $5.51 \%$ & $3.88 \%$ & $-2.56 \%$ & $-4.00 \%$ \\
5 & $7.97 \%$ & $5.06 \%$ & $6.66 \%$ & $4.36 \%$ & $-2.84 \%$ & $-4.25 \%$ \\
6 & $2.43 \%$ & $2.06 \%$ & $2.24 \%$ & $1.90 \%$ & $-3.56 \%$ & $-4.44 \%$ \\
7 & $0.00 \%$ & $0.25 \%$ & $0.16 \%$ & $0.32 \%$ & $-4.40 \%$ & $-5.04 \%$ \\
8 & $-0.29 \%$ & $-0.02 \%$ & $-0.13 \%$ & $0.06 \%$ & $-4.41 \%$ & $-4.99 \%$ \\
\hline
\end{tabular}


bridges, in percentage in the ordinates. Negative results are related to the fact that the model with bridges reached higher consumption than the model without them.

Total consumption is the addition of consumption for heating and for cooling in a 1-year period. It is important to notice that consumption for cooling is more than $95 \%$ of the total and that makes consumption for heating less significant. However, regarding heating, the model with thermal bridges presents around $40 \%$ more consumption in all bioclimatic zones, except for the eight ones, which do not have heating consumption.

Results in the city of Curitiba (BZ1) show that, for the lower numbers of ILD and LPD combined with higher gains for conduction through glass, thermal bridges increase consumption by $1 \%$ to $2 \%$. For higher ILD and LPD combined with higher gains for conduction through glass, consumption is increased in almost 5\%. Like in bioclimatic zone 1, in Zones 2 to 5, closures with thermal bridges provide a decrease of $6 \%$ to $4 \%$ in total consumption, for WWR of $30 \%$ and $45 \%$. In the warmer zones (6 to 8 ), percentage gradually decreases, getting close to 0 . Regarding WWR $60 \%$, similarly to BZ1, there were increases in all zones of $3.09 \%, 4.40 \%, 3.93 \%, 4.00 \%, 4.25 \%$, $4.44 \%, 5.04 \%$ and $4.99 \%$, respectively.

In Zones 1 to 5 , it is possible to notice a bigger reduction of consumption, getting to $10 \%$ in Curitiba (BZ1). In colder zones, where the temperature difference between inside and outside of the building is higher, heat transmittance through thermal bridges gets easier and decreases the consumption of electric energy in the building, especially with cooling, since the loss of heat is natural.

\section{Conclusions}

Observing the results obtained, it is possible to understand the importance of considering thermal bridges when calculating the buildings' energy performance. Observing the eight Brazilian bioclimatic zones, it is possible to define that the disconsideration of the thermal bridges in hotel buildings with WWR $30 \%$ and $45 \%$, in energy modeling, implies a decrease of estimated consumption that can get to $10 \%$, depending on the bioclimatic zone. For $60 \%$ WWR, not considering thermal bridges can represent up to $5 \%$ increase in consumption, depending on the bioclimatic zone. In these cases, the cooling consumption represents the major percentage of the end use energy, wall thermal transmittance decrease and thermal resistance increase, which hinder heat loss. In these cases, 60\% WWR, solar heat gain is high. For this reason, the building has expressive solar heat gain and more insulated envelope resulting, therefore, on a cooling consumption increase.

\section{References}

[1] ABNT (Brazilian Technical Standards Association). 2013. NBR 15.575. Desempenho de Edificios Habitacionais (Residencial Buildings Thermal Performance). Rio de Janeiro: ABNT. (in Portuguese)

[2] ABNT. 2005. NBR 15.220. Norma Brasileira de Desempenho Térmico de Edificações, Parte 3: Zoneamento Bioclimático Brasileiro e Diretrizes Construtivas para Habitações Unifamiliares de Interesse Social (Brazilian Standard of Buildings Thermal Performance. Part 3: Brazilian Bioclimatic Zoning and Constructive Guidelines for Social Interest Housing). Rio de Janeiro: ABNT. (in Portuguese)

[3] Matos, M. 2007. Simulação Computacional do Desempenho Térmico de Residências em Florianópolis Utilizando a Ventilação Natural (Thermal Performance Modeling of Housing in Florianopolis Using Natural Ventilation). Florianópolis: UFSC (Federal University of Santa Catarina). (in Portuguese)

[4] Pereira, C. 2009. "A Influência do Envelope no Desempenho Térmico de Edificações Residenciais Unifamiliares Ocupadas e Ventiladas Naturalmente (The Envelope Influence in the Thermal Performance of an Occupied and Naturally Ventilated Housing)." M.Sc. dissertation, Federal University of Santa Catarina. (in Portuguese)

[5] Venâncio, R. 2011. "Investigando o Projeto de Envoltória: Questionário Sobre Prática Arquitetônica e Desempenho Térmico (Investigating the Envelope Architectonic Project: Survey about the Architectonic Project and 
Thermal Performance)." Presented at XI Nacional Meeting of Environmental Confort of the Constructed Environment, Búzios. (in Portuguese)

[6] Carlo, J. C. 2008. "Desenvolvimento de Metodologia de Avaliação da Eficiência Energética do Envoltório de Edificações Não-residenciais (Developing of Energy Efficiency Evaluation Methodology of Non-residential Buildings Envelope).” Ph.D. thesis, Federal University of Santa Catarina. (in Portuguese)

[7] Inmetro-National Institute of Metrology, Standardization and Industrial Quality. 2012. Requisitos Técnicos da Qualidade para o Nivel de Eficiência Energética de Edifícios Comerciais, de Serviços e Públicos (Brazilian Technical Regulation for Energy Efficiency in Commercial, Services and Public Buildings) $-R T Q-C$. Brazil: Eletrobrás. (in Portuguese)

[8] Evans, J. M., and de Schiller, S. 2010. "Verificación de Puentes Térmicos Normas Para Definir Soluciones Admisibles (Verification of Thermal Bridges Standard in Order to Define Permissible Solutions)." Avances en
Energias Renovables y Medio Ambiente (Advances in Renewable Energies and Environment) 14: 51-8. (in Spanish)

[9] Instituto Argentino de Normalización (Argentine Institute for Standardization and Certification). 2002. IRAM 11549. Aislamiento Térmico de Edificios (Buildings Thermal Insulation). Argentina: IRAM. (in Spanish)

[10] Haupt, W. 2007. Skript Feuchsteschutz (Protection against Moisture Script). Kassel: University of Kassel. (in German)

[11] Valério, J. G. M. A. P. 2007. “Avaliação do Impacte das Pontes Térmicas no Desempenho Térmico e Energético de Edifícios Residenciais Correntes (Evaluation of the Thermal Bridges Impacts in the Thermal and Energy Performance of Residential Buildings).” M.Sc. thesis, Technical Institute of Lisbon. (in Portuguese)

[12] ABNT. 2008. NBR 16401-1. Instalações de Ar-condicionado-Sistemas Centrais e Unitário Parte 1: Projetos das Instalaçõe (Air Conditioning System-Central and Unitary System. Part 1: Instalation Project). Rio de Janeiro: ABNT. (in Portuguese) 